\title{
Comet-tail artefacts and abdominal pain: radiological mistake or an underestimated event?
}

\author{
Paola Marchetti, Francesco De Peppo, Emanuela Ceriati, Ottavio Adorisio
}

Department of Pediatric Surgery, Bambino Gesù Children's Hospital, Palidoro, Italy

\section{Correspondence to}

Dr Ottavio Adorisio, o.adorisio@yahoo.it
To cite: Marchetti P, De Peppo F, Ceriati E, et al. BMJ Case Rep Published online: [please include Day Month Year] doi:10.1136/ bcr-2013-009896

\section{DESCRIPTION}

The comet-tail artefact appears as a dense tapering trail of echoes just distal to a strongly reflecting structure. This reverberation type of artefact occurs when there is a marked difference in acoustic impedances between an object and its surrounding. ${ }^{1}$ A 12-year-old boy presented with a short history of acute abdominal pain without vomiting and fever was studied with an abdominal ultrasound showing the presence of multiple small echogenic foci with comet-tail artefact (figure 1). On subsequent MRI, these lesions were hyperintense on T2-weighted and hypointense on T1-weighted images, respectively (figure 2). A cause of abdominal pain was identified in a concomitant acute adenomesenteritis. Comet-tail artefact arises from reverberation of the US beam within a small cyst or gas bubble. The multiple echoes generated register as a trail on the image.

The appearance may also be seen with von Meyenburg complexes, a benign condition found in up to $5 \%$ of the population.

Comet-tail artefact must be differentiated from the ring-down artefact. In the past, it has been thought that the ring-down artefact was a variant of comet-tail artefact because of a similar US appearance. Despite this, these two artefacts have separate mechanisms. In ring-down artefact, the transmitted ultrasound energy causes resonant vibrations within fluid trapped between a tetrahedron of air bubbles. These vibrations create a continuous sound wave. This phenomenon is displayed as a line or series of parallel bands extending posterior to a gas collection. ${ }^{2}$

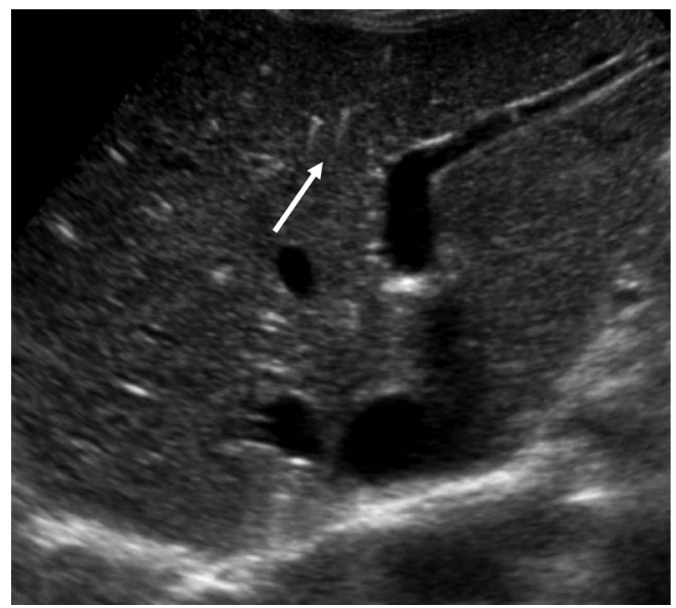

Figure 1 Abdominal ultrasound showing the presence of multiple small echogenic foci with comet-tail artefact (white arrow).

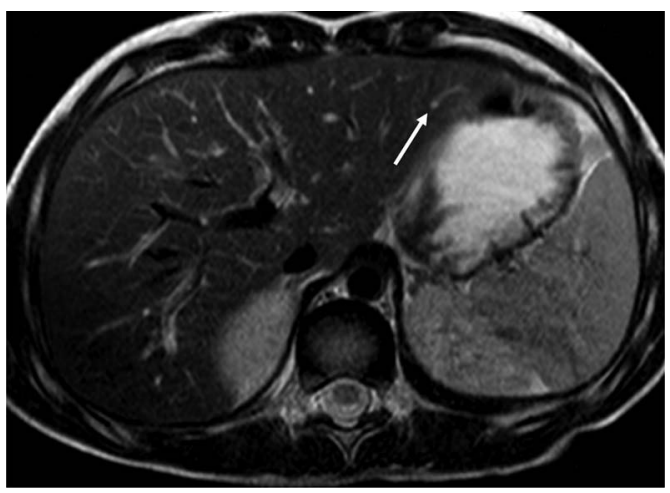

Figure 2 Abdominal MRI showing how these lesions were hyperintenses on T2 (white arrow).

The comet-tail artefact is a grey-scale US finding seen when small calcific/crystalline highly reflective objections are found, and is believed to be a special form of reverberation artefact. ${ }^{3}$ The artefact often is helpful in situations in which grey-scale imaging does not provide adequate information for a conclusive diagnosis.

\section{Learning points}

- The presence of comet-tail artefacts could avoid unnecessary invasive (ie, liver biopsy) or non-invasive (ie, CT) approaches.

- The artefact often is helpful in situations in which grey-scale imaging does not provide adequate information for a conclusive diagnosis.

Contributors PM and FDP followed the patient during the hospital stay; EC performed the follow-up and OA was the supervisor.

Competing interests None.

Patient consent Obtained.

Provenance and peer review Not commissioned; externally peer reviewed.

\section{REFERENCES}

1 Ziskin MC, Thickman DI, Goldenberg NJ, et al. The comet tail artifact. J Ultrasound Med 1982;1:1-7.

2 Feldman MK, Katyal S, Blackwood MS. US artifacts. Radiographics 2009;29:1179-89.

3 Tchelepi H, Ralls PW. Color comet-tail artifact: clinical applications. AJR Am J Roentgenol 2009;192:11-18. 


\section{Images in...}

Copyright 2013 BMJ Publishing Group. All rights reserved. For permission to reuse any of this content visit http://group.bmj.com/group/rights-licensing/permissions.

BMJ Case Report Fellows may re-use this article for personal use and teaching without any further permission.

Become a Fellow of BMJ Case Reports today and you can:

- Submit as many cases as you like

- Enjoy fast sympathetic peer review and rapid publication of accepted articles

- Access all the published articles

- Re-use any of the published material for personal use and teaching without further permission

For information on Institutional Fellowships contact consortiasales@bmjgroup.com

Visit casereports.bmj.com for more articles like this and to become a Fellow 